\title{
Akılcı olmayan ilaç kullanım davranışları: Ankara'da üç ilçe örneği
}

\author{
Mustafa Necmi İlhana, Önder Aydemirb, Mustafa Çakırc, Sefer Aycand
}

\section{Özet}

Amaç: Akılcı olmayan ilaç kullanımının olumsuz etkilerinin önüne geçilebilmesi için toplumun ilaç kullanım özelliklerinin araştırılmasına yönelik bilimsel çalışmaların yapılması gerekmektedir. $\mathrm{Bu}$ çalışmanın amacl; Ankara il merkezinde üç ilçedeki bazı aile sağlığı merkezlerine başvuran 18 yaş üstü kişilerin ilaç kullanım özelliklerinin değerlendirilmesidir. Yöntem: Tanımlayıcı tipteki araştırma, Ankara il merkezinde üç ilçedeki bazı aile sağlı̆̆ merkezlerine başvuran 18 yaş üstü 1990 kişinin katılımıyla anket formu uygulanarak yapılmıştır. Bulgular: Katılımcıların yarısından daha azı bir sağlık sorunuyla karşılaştıklarında sağlık kuruluşuna başvurduğunu belirtmiştir; \%78.6'sı evde ilaç bulundurmaktadır ve bunların \%40.3'ü ağrı kesicilerdir. Katılımcıların \%60.9'u ilaçların kullanma talimatını okuduğunu, \%56.9'u reçete ile alınan ilaçları tam olarak kullandığını söylemiştir. Katılımcılardan 55 yaş ve üzerindekilerin \%68.9'u, kadınların \%63.0'ı, evli olanların \%63.3'ü, okuryazar olmayanların \%71.2'si, ev kadınlarının \%70.6'sı, aylık toplam geliri 1001 TL ile 1500 TL arasında olanların \%68.9'u, hanesinde sürekli ilaç kullanan olan katılımcıların \%68.8'i doktora istediği ilacı yazdırmayı talep ettiğini belirtmiştir $(\mathrm{p}<0.05)$. Sonuç: Bu çalışmada, katılımcıların yaklaşık yarısının herhangi bir sağlık sorunu olduğunda sağlık kuruluşuna başvurmadığı, azımsanamayacak bir kısmının ise evdeki ilaçları kullanma, bitkisel/geleneksel yöntem kullanma gibi yollara başvurduğu saptanmıştır. Akılcı ilaç kullanım ilkeleriyle bağdaşmayan bu gibi davranışların önüne geçilebilmesi için toplumu oluşturan bireylere akılcı ilaç kullanımına yönelik halk eğitimlerinin yapılması gerekmektedir.

Anahtar Kelimeler: Akılcı ilaç kullanımı, reçete, tanımlayıcı

\section{A Study in Three Districts of Ankara of Behaviors Associated With Irrational Use of Drugs}

\begin{abstract}
Objective: To avoid the irrational use of medicines studies have to be conducted to evaluate the habits related to drug use. This study investigated the characteristics of individuals aged above 18 in using of medicines among in Family Health Care Centers in the city center of Ankara.

a Prof. Dr., Gazi Üniversitesi Tıp Fakültesi Halk Sağlığı Anabilim Dalı, Ankara.

b Arş. Gör. Dr., Gazi Üniversitesi Tıp Fakültesi Halk Sağlı̆̆ı Anabilim Dalı, Ankara.

c Arş. Gör. Dr., Gazi Üniversitesi Tıp Fakültesi Halk Sağlığı Anabilim Dalı, Ankara.

d Prof. Dr., Gazi Üniversitesi Tıp Fakültesi Halk Sağlığı Anabilim Dalı, Ankara.
\end{abstract}

Sorumlu Yazar: Önder Aydemir, Arş. Gör. Dr., Gazi Üniversitesi Tıp Fakültesi Halk Sağlığı Anabilim Dalı, Ankara. Telefon: +90 312202 4732, E mail: onder_aydem@hotmail.com

Gelis tarihi: 12.11.2013, Kabul tarihi: 17.11.2014

Turk J Public Health 2014;12(3) 
Methods: This is a descriptive study. A questionnaire was applied to 1990 individuals aged above 18 in several Family Health Care Centers in the city center of Ankara. Results: Less than half of the applicants stated that they attended a health care institution for a health problem; $78.6 \%$ stated that they keep medicine at home that $40.3 \%$ of those medicines were painkillers. $60.9 \%$ of the applicants claimed they read the instructions provided with the medicine; $57.0 \%$ of the applicants claimed to use the prescribed medicine exactly as instructed. $68.9 \%$ of those aged 55 and above of the applicants, $63.0 \%$ of the women, $63.3 \%$ of the married women, $71.2 \%$ of illiterates, $70.6 \%$ of housewives, $68.9 \%$ of those having monthly income between $1001-1500 \mathrm{TL}$, and $68.8 \%$ of those who had someone with chronic disease at home claimed that they would ask the doctor to prescribe the medicines they wanted $(\mathrm{p}<0.05)$. Conclusion: Almost half of the participants did not apply to a health care institution and a substantial portion of them used home remedies in case of a health problem. In order to reduce irrational drug use, public education for rational use of medicines needs to be implemented.

Keywords: Rational use of medicine, prescription, descriptive

\section{Giriş}

Dünya Sağlık Örgütü (DSÖ) 1985 yılında Nairobi'de düzenlenen bir toplantıda, akılcı ilaç kullanımını (AİK); "hastaların ilaçları klinik gereksinimlerine uygun biçimde, kişisel gereksinimlerini karşılayacak dozlarda, yeterli zaman diliminde, kendilerine ve topluma en düşük maliyette almaları için uyulması gereken kurallar bütünü" olarak tanımlamıştır. ${ }^{1}$

Akılcı olmayan ilaç kullanımı (AOİK) bütün dünyada, özellikle de gelişmekte olan ülkelerde en temel sağlık sorunlarından birisidir ve vazgeçilmesi güç bir alışkanlıktır. Bu sorun gelişmiş ülkelerde çok sayıda kapsamlı çalışmayla ortaya konmuş ve sorunun çözümünde belirli bir aşama kaydedilmiştir. Oysa gelişmekte olan ülkelerde bu konuda yeterli çalışma yapılmadığı için AOİK'nın boyutları ve nedenleri saptanamamıştır. ${ }^{2}$

Akılcı olmayan ilaç kullanımını
araştıran az sayıdaki çalışmalarda
belirlenen temel sorunlar arasında;
gereğinden fazla ilaç reçetelendirilmesi,
ilaçların yanlış biçimde kullanılması,
gereksiz yere pahalı ilaçların kullanımı ya da
gereksiz yere antibiyotik tüketimi gibi AİK
yaklaşımının yeterince uygulanamamasına
bağlı sorunlar gözlenmiştir. AOİK'nın eğitim
eksikliğinden başlayarak sosyokültürel,
ekonomik, yönetsel ve düzenleyici
mekanizmalardan kaynaklanan birçok
nedeni vardır.

Kullanıcılar, sağlık hizmeti veren kurumların hizmetlerini kullanarak sağlık profesyonelleri tarafından önerilen tedavileri alsalar bile, ilaç kullanımını son olarak belirleyen onların karar verme mekanizmaları olmaktadır. $\mathrm{Bu}$ kararlar; ailenin, arkadaşların veya toplumun inançları, reçete yazanlarla ilaç hazırlayıcılardan alınan bilgiler ve teșvik edici şeyler gibi faktörlerden etkilenebilmektedir. Son yıllarda Sağlıkta Dönüşüm Programı kapsamında gerek geri ödeme sistemindeki değişiklikler, gerekse sağlık kuruluşlarının tek çatı altında toplanması ve aile hekimliği uygulamasına geçilmesi gibi sağlık sistemimizde çok önemli değiş̧iklikler yaşanmaktadır ve bu temel yapısal değişimler, hastaların ilaç kullanımı alışkanlıklarına da yansımış olabilir. ${ }^{3}$ Kişiler, hasta olduklarında, daha önceki deneyimlerinden hareketle; ellerinde mevcut ilaçlardan herhangi birini kullanabilmekte, yakınlarının tavsiyesi ile ilaç alabilmekte ya da eczaneden doğrudan aldıkları kimi ilaçları kullanabilmektedirler. Dahası bu yanlış davranışlar doktora başvurduktan sonraki aşamalarda da devam edebilmektedir. ${ }^{4}$ İlaçların hekimin belirttiği ve / veya kullanma talimatında belirtilen doz ve biçimden farklı kullanılması, semptomların ortadan kalkmasına bağlı olarak öngörülen süreden önce kesilmesi; olumsuz tıbbi sonuçların nedeni olabileceği gibi; evde bulundurulan kullanılmayan ilaçların sayısını da zamanla artırmaktadır ki bu bir AOIK sorunudur.

\section{Turk J Public Health 2014;12(3)}


AOİK'nın olumsuz etkilerinin önüne geçilebilmesi için toplumun ilaç kullanım özelliklerinin araştırılmasına yönelik bilimsel çalışmaların yapılması gerekmektedir.

$\mathrm{Bu}$ çalışmanın amacl; Ankara İl Merkezi'nde üç ilçedeki bazı aile sağlığı merkezlerine başvuran on sekiz yaş üstü kişilerin bazı ilaç kullanım özelliklerinin değerlendirilmesidir.

\section{Gereç ve yöntem}

Tanımlayıcı tipteki bu araştırma, Gazi Üniversitesi Tıp Fakültesi Halk Sağlığı Anabilim Dalı eğitim ve araştırma bölgeleri olan, Ankara İl Merkezi, Sincan, Etimesgut, Gölbaşı İlçelerindeki toplam 6 Aile Sağlığı Merkezine 2013 yılının Ocak ve Şubat aylarında iki hafta boyunca başvuran 18 yaş üstü 1990 kişinin katılımıyla yürütülmüştür.

Araştırma kapsamında, belirtilen tarihler arasında Aile Sağlığı Merkezlerine başvuran 18 yaş üstü kișilerin tamamının incelenmesi hedeflenmiştir. Hazırlanan anket formunun uygulandığı 8 gün boyunca farklı saat dilimlerinde başvuranlarla görüşülmüş, araştırmanın amacı hakkında bilgi verilmiş, onayları alındıktan sonra çalışma kapsamına dâhil edilmiştir. Araştırmanın yapıldığı tarihler arasında Aile Sağlığ başvurduğu belirlenmiş, $\% 50$ sıklık alınarak, \%2 sapma ve \%95 güven düzeyinde 2005 kişiye ulaşılması hedeflenmiştir. Araştırma kapsamında toplam 1990 kişiye (\%99.2) ulaşılmıştır.

Araștırmada veri kaynağı olarak "Ankara İl Merkezlerinde Bazı Sağlık Kurumlarına Başvuran 18 Yaş Üstü Kişilerin İlaç Kullanım Alışkanlıkları" başlıklı anket formu hazırlanmıștır ve yüz yüze görüşme yöntemiyle uygulanmıştır. Bir anketin uygulama süresi ortalama 8-10 dakikadır. Hazırlanan anket formu toplam 22 sorudan olușmaktadır. Anket formu aracılığıyla kişilerin ilaç kullanım özellikleri ile ilgili bilgiler sorgulanmıştır.

Araştırmanın tanımlayan değişkenleri cinsiyet, yaş, medeni durum, eğitim durumu, meslek, aylık toplam hane halkı geliri, hanede hekim tarafından tanısı konulmuş herhangi kronik hastalık varlığı, hanede hekim tarafından verilmiş düzenli ilaç kullanma durumudur. Tanımlanan değişkenleri ise; hekime bazı ilaçları yazdırma durumu, hekim önerisi ve reçetesi dışında ilaç kullanma durumu ve reçete ile alınan ilaçları tam olarak kullanma durumu olarak belirlenmiştir.

paket programı aracılığıla değerlendirilmiştir. Tanımlayıcı istatistikler ortalama ( \pm ) standart sapma, ortanca (min ; max), frekans dağılımı ve yüzde olarak sunulmuştur. İstatistiksel anlamlılık düzeyi $\mathrm{p}<0.05$ olarak kabul edilmiştir. Tanımlayıcı istatistiklerin yanı sıra ki-kare ve Yates düzeltmeli ki-kare testi istatistiksel yöntem olarak kullanılmıștır.

\section{Bulgular}

Araştırma kapsamında 1990 kişiye ulaşılmıştır. Araştırmaya katılanların bazı tanımlayıcı özelliklerinin dağılımı Tablo 1'de sunulmuştur.

Araştırmaya katılanların \%25.3'ü 24-35 yaş arasında olup yaş ortalaması 42.0 15.0 , ortancası 40.0'dır (min:18-maks: 92). Katılımcıların \%56.9'u kadın, \%72.8'i evli, \%32.6'sı lise mezunu, \%31.8'i ev kadını, \%23.8'i memur, \%26.3'ü 1501-2000 TL aylık gelire sahip olduğunu, \%52.6'sı hanesinde kronik hastalık olduğunu, \%48.0'ı hanesinde sürekli ilaç kullanıldığını ifade etmiştir.

Tablo 2'de araştırmaya katılanların evde ilaç bulundurma durumu, bulundurdukları ilaçların türleri ve temin etme yollarının dağılımı sunulmuştur. Katılımcıların \%78.6'sı evde ilaç bulundurduğunu ifade etmiş, hangi tür ilaçları bulundurdukları sorulduğunda verilen cevapların \%40.3'ü ağrı kesici, \%19.2'si soğuk algınlığı ilaçları, \%15.6'sı mide ilaçları, \%14.5'i antibiyotik şeklinde, evde bulundurdukları ilaçları nereden temin ettikleri sorulduğunda verilen cevapların $\% 40.8$ 'i doktordan yazmasını isteme, 
\%38.2'si önceki tedavilerden kalanlar, \%15.1'i eczacıya danışarak alma şeklinde olmuştur.

Tablo 1. Katılımcların tanımlayıcı özelliklerinin dağılımı, Ankara, 2013

\begin{tabular}{|c|c|c|}
\hline Özellikler & Sayı & $(\%)^{*}$ \\
\hline \multicolumn{3}{|l|}{ Yaş grupları $(n=1990)$} \\
\hline 18-24 yaș & 240 & 12.1 \\
\hline $25-34$ yaș & 504 & 25.3 \\
\hline $35-44$ yaș & 409 & 20.5 \\
\hline $45-54$ yaş & 410 & 20.6 \\
\hline 55 yaș ve üzeri & 427 & 21.5 \\
\hline \multicolumn{3}{|l|}{ Cinsiyet $(n=1990)$} \\
\hline Erkek & 858 & 43.1 \\
\hline Kadın & 1132 & 56.9 \\
\hline \multicolumn{3}{|l|}{ Medeni durum (n=1990) } \\
\hline Evli & 1448 & 72.8 \\
\hline Bekâr & 542 & 27.2 \\
\hline \multicolumn{3}{|c|}{ Öğrenim durumu (n=1989) } \\
\hline Okuryazar değil & 66 & 3.3 \\
\hline Okuryazar & 110 & 5.5 \\
\hline İlkokul mezunu & 243 & 12.2 \\
\hline Ortaokul mezunu & 361 & 18.2 \\
\hline \multirow{2}{*}{$\begin{array}{l}\text { Lise mezunu } \\
\text { Yüksekokul-üniversite } \\
\text { mezunu }\end{array}$} & 648 & 32.6 \\
\hline & 561 & 28.2 \\
\hline \multicolumn{3}{|l|}{ Meslek (n=1985) } \\
\hline Öğrenci & 125 & 6.3 \\
\hline Ev hanımı & 631 & 31.8 \\
\hline İșsiz & 61 & 3.1 \\
\hline İşçi & 197 & 9.9 \\
\hline Memur & 472 & 23.8 \\
\hline Emekli & 229 & 11.5 \\
\hline Serbest & 270 & 13.6 \\
\hline \multicolumn{3}{|c|}{ Aylık aile toplam geliri $(n=1986)$} \\
\hline 1000 tl ya da daha az & 301 & 15.2 \\
\hline $1001 \mathrm{tl}-1500 \mathrm{tl}$ & 492 & 24.8 \\
\hline $1501 \mathrm{tl}-2000 \mathrm{tl}$ & 522 & 26.3 \\
\hline $2001 \mathrm{tl}-5000 \mathrm{tl}$ & 525 & 26.4 \\
\hline 5000 tl'den fazla & 146 & 7.3 \\
\hline \multicolumn{3}{|c|}{ Hanede kronik hastalık varlığı (n=1649) } \\
\hline Yok & 782 & 47.4 \\
\hline Var & 867 & 52.6 \\
\hline \multicolumn{3}{|c|}{ Hanede engellilik varlığı $(n=1611)$} \\
\hline Yok & 1572 & 97.6 \\
\hline Var & 39 & 2.4 \\
\hline \multicolumn{3}{|c|}{$\begin{array}{l}\text { Hanede sürekli ilaç kullanma durumu } \\
(n=1640)\end{array}$} \\
\hline Yok & 852 & 52.0 \\
\hline Var & 788 & 48.0 \\
\hline
\end{tabular}

*Sütun yüzdesi
Tablo 3'te araştırmaya katılanların sağlık sorunu olduğunda başvurdukları yöntemler, hekimlerden istedikleri ilacı yazmasını talep etme durumları, hekim önerisi dışında ilaç kullanma durumları, nedenleri, kullandıkları ilaçlar ve yakınlarının tavsiyesiyle ilaç kullanma durumlarının dağılımı sunulmuştur.

Katılımcıların sağlı sorunuyla karşılaştıklarında başvurdukları yöntemlerin neler olduğu sorusuna verdikleri cevapların \%59.5'i sağllk kurulușuna bașvurma, \%30.2'si evde bulunan ilaçları kullanma ve \%20.8'i bitkisel ilaç / geleneksel yöntem kullanma șeklinde olmuștur. Katılımcıların \%44.0'ı hekimden kendi istediği ilaçları yazmasını istediğini, \%62.0'ı hekim önerisi dışında ilaç kullandığını ifade etmiştir. Araștırmaya katılanlara hekim önerisi dışında ilaç kullanma nedenleri sorulduğunda cevapların \%55.3'ü doktora gitmeye gerek duymama, \%21.5'i muayene ücreti vermek istememe ve \%21.2'si doktora gitmeye vakti olmama şeklinde olmuştur. Katılımcıların \%49.5'i son bir ayda hekim önerisi dışında ilaç kullandığını, \%14.1'i yakınlarının tavsiyesi üzerine ilaç kullandığını belirtmiştir.

Tablo 4'te araştırmaya katılanların kullandıkları ilaçların kullanım talimatını okuma durumları, ilaç kullanırken dikkat ettikleri durumlar, kullanılmayan ilaçların durumları ve reçete ile alınan ilaçların tam olarak kullanılma durumlarının dağılımı sunulmuştur.

Katılımcılara ilaç kullanırken nelere dikkat ettikleri sorulduğunda verdikleri cevapların \%53.3'ü doktor tavsiyesi, \%15.4'ü eczacl tavsiyesi, \%15.1'i yakın/komşu tavsiyesi, $\% 10.4$ 'ü yazılı/görsel basın ve \%5.4'ü internet șeklindedir. Araștırmaya katılanlara kullanmadıkları ilaçları ne yaptıkları sorulduğunda cevapların \%60.3'ü buzdolabında saklama, \%18.0'ı çöpe atma ve \%10.2'si sağlı kuruluşlarına verme şeklinde olmuştur. 
Tablo 2. Araştırmaya katılanların evde ilaç bulundurma durumu, bulundurdukları ilaçların türleri ve temin etme yollarının dağılımı, Ankara, 2013

\begin{tabular}{|c|c|c|}
\hline Özellikler & Sayı & $(\%)^{*}$ \\
\hline \multicolumn{3}{|l|}{ Evde ilaç bulundurma durumu $(n=1979)$} \\
\hline Bulunduruyor & 1555 & 78.6 \\
\hline Bulundurmuyor & 424 & 21.4 \\
\hline \multicolumn{3}{|l|}{ Evde bulundurulan ilaç türleri $(n=1546) \#$} \\
\hline Ağrı kesici & 1462 & 40.3 \\
\hline Soğuk algınlığı ilaçları & 699 & 19.2 \\
\hline Mide ilacı & 568 & 15.6 \\
\hline Antibiyotik & 527 & 14.5 \\
\hline Vitamin & 356 & 9.8 \\
\hline Diğer** & 14 & 0.6 \\
\hline \multicolumn{3}{|c|}{ Evde bulunan ilaçları temin etme yolları ( $n=1549) \#$} \\
\hline $\begin{array}{l}\text { Doktordan yazmasını } \\
\text { isteme }\end{array}$ & 1089 & 40.8 \\
\hline $\begin{array}{l}\text { Önceki tedavilerden } \\
\text { kalanları kullanma }\end{array}$ & 910 & 38.2 \\
\hline Eczacıya danışarak alma & 403 & 15.1 \\
\hline $\begin{array}{l}\text { Arkadaşlardan / } \\
\text { tanıdıklardan } \\
\text { duyduklarını alma }\end{array}$ & 129 & 5.1 \\
\hline $\begin{array}{l}\text { Arkadaşlardan / } \\
\text { tanıdıklardan alma }\end{array}$ & 138 & 0.8 \\
\hline \multicolumn{3}{|c|}{$\begin{array}{l}\text { *Sütun yüzdesi, \#Birden fazla yanıt verilmiştir. Yüzdeler toplam yanıt verilen sayı üzerinden } \\
\text { değerlendirilmiştir, }{ }^{* *} \text { Diğer: Antihipertansif ilaçlar, antidiyabetik ilaçlar, astım ilacı, öksürük ilacı, } \\
\text { antihiperlipidemik ilaçlar }\end{array}$} \\
\hline $\begin{array}{l}\text { Katılımcıların \%56.9'u reçete ile alınan } \\
\text { ilaçları tam olarak kullandığını, \%32.3'ü } \\
\text { bazen tam olarak kullandığını ve \%10.8'i } \\
\text { tam olarak kullanmadığını ifade etmiştir. } \\
\text { Katılımcıların \%60.9'u kullandıkları ilaçları } \\
\text { kullanma talimatını okuduğunu belirtmiştir. }\end{array}$ & \multirow{3}{*}{\multicolumn{2}{|c|}{$\begin{array}{l}1001 \text { TL ile } 1500 \text { TL arasında olanların } \\
\% 68.9 \text { 'u, hanesinde kronik hastalık } \\
\text { olanların \%68.2'si, hanelerinde engelli kişi } \\
\text { olanların \%69.2'si ve hanesinde sürekli ilaç } \\
\text { kullanan kişi olanların \%68.8'i hekime } \\
\text { gittiğinde istediği ilacı yazdırmayı talep } \\
\text { ettiğini belirtmiştir. Katılımcıların yaş } \\
\text { gruplarına, medeni durumlarına, öğrenim } \\
\text { durumlarına, mesleklerine, aylık toplam } \\
\text { gelirlerine, hanede kronik hastalık varlığına } \\
\text { ve hanede sürekli ilaç kullanma durumuna } \\
\text { göre doktora gittiğinde istedikleri ilacı } \\
\text { yazdırmayı talep etme durumu arasında } \\
\text { istatistiksel olarak anlamlı bir fark } \\
\text { saptanmıştır (p<0.05). Yaş, öğrenim } \\
\text { durumu, meslek ve aylık toplam hane geliri } \\
\text { grupları arasındaki fark birden fazla } \\
\text { gruptan kaynaklanmaktadır. }\end{array}$}} \\
\hline $\begin{array}{l}\text { Tablo 5'te araştırmaya katılanların } \\
\text { bazı tanımlayıcı özelliklerine göre doktora } \\
\text { gidildiğinde istedikleri ilaçları yazdırmayı } \\
\text { talep etme durumunun dağılımı } \\
\text { sunulmuştur. }\end{array}$ & & \\
\hline $\begin{array}{l}\text { Katılımcılardan } 24 \quad \text { yaş ve } \\
\text { altındakilerin \%50.4'ü, } 55 \text { yaş ve } \\
\text { üzerindekilerin \%68.9'u, kadınların \%63.0'ı, } \\
\text { evli olanların \%63.3'ü, yüksekokul- } \\
\text { üniversite mezunu olanların \%52.8'i, ev } \\
\text { hanımlarının \%70.6'sl, aylık toplam geliri }\end{array}$ & & \\
\hline
\end{tabular}

Turk J Public Health 2014;12(3) 
Tablo 3. Araştırmaya katılanların sağlık sorunu olduğunda başvurdukları yöntemler, hekimlerden istedikleri ilacı yazmasını talep etme durumları, hekim önerisi dışında ilaç kullanma durumları, nedenleri, kullandıkları ilaçlar ve yakınlarının tavsiyesiyle ilaç kullanma durumlarının dağılımı, Ankara, 2013

\begin{tabular}{|c|c|c|}
\hline Özellikler & Sayı & $(\%)^{*}$ \\
\hline \multicolumn{3}{|c|}{ Sağlık sorunu olduğunda bașvurulan yöntemler (n=1967)\# } \\
\hline Sağllk kuruluşuna bașvurma & 1170 & 59.5 \\
\hline Evdeki ilaçlardan kullanma & 593 & 30.2 \\
\hline Bitkisel/geleneksel yöntem kullanma & 410 & 20.8 \\
\hline Hiçbir şey yapmama & 160 & 8.1 \\
\hline Eczacıya danışarak ilaç alma & 158 & 8.0 \\
\hline Arkadaş, tanıdık tavsiyesi ile ilaç kullanma & 54 & 2.7 \\
\hline \multicolumn{3}{|c|}{ Hekimden istenilen ilacı yazmasını talep etme durumu $(n=1970)$} \\
\hline Talep etmiyor & 762 & 66.0 \\
\hline Talep ediyor & 1208 & 44.0 \\
\hline \multicolumn{3}{|c|}{ Hekim önerisi dışında ilaç kullanma durumu $(n=1969)$} \\
\hline Kullanıyor & 1220 & 62.0 \\
\hline Kullanmiyor & 749 & 38.0 \\
\hline \multicolumn{3}{|c|}{ Hekim önerisi dışında kullanmanın nedenleri (n=1204)\# } \\
\hline Doktora gitmeye gerek duymama & 777 & 55.3 \\
\hline Muayene ücreti vermek istememe & 303 & 21.5 \\
\hline Doktora gitmeye vakti yok & 299 & 21.2 \\
\hline Diğer** & 26 & 2.0 \\
\hline \multicolumn{3}{|c|}{ Hekim önerisi dışında kullanılan ilaçlar $(n=1213) \#$} \\
\hline Ağrı kesici & 1058 & 44.6 \\
\hline Soğuk algınlığı ilaçları & 513 & 21.6 \\
\hline Mide ilacı & 365 & 15.4 \\
\hline Antibiyotik & 236 & 9.9 \\
\hline Vitamin & 189 & 7.9 \\
\hline Diğger*** & 6 & 0.6 \\
\hline \multicolumn{3}{|c|}{ Son bir ayda hekim önerisi dışında ilaç kullanma durumu $(n=1902)$} \\
\hline Kullanmamıș & 961 & 50.5 \\
\hline Kullanmış & 941 & 49.5 \\
\hline \multicolumn{3}{|c|}{ Son bir ayda hekim önerisi dıșında kullanılan ilaçlar (n=931)\# } \\
\hline Ağrı kesici & 682 & 53.1 \\
\hline Soğuk algınlığı ilaçları & 225 & 17.5 \\
\hline Mide ilacl & 171 & 13.3 \\
\hline Antibiyotik & 111 & 8.6 \\
\hline Vitamin & 83 & 6.4 \\
\hline Diğer*** & 11 & 1.1 \\
\hline \multicolumn{3}{|c|}{ Yakınlarının tavsiyesiyle ilaç kullanma durumu $(\mathrm{n}=1940)$} \\
\hline Kullanmiyor & 1075 & 55.4 \\
\hline Bazen kullanıyor & 592 & 30.5 \\
\hline Kullanıyor & 273 & 14.1 \\
\hline
\end{tabular}

*Sütun yüzdesi, \#Birden fazla yanıt verilmiştir. Yüzdeler toplam yanıt verilen sayı üzerinden değerlendirilmiştir, **Diğer: Doktora gitmek istememe, Tv'de gördüğü ilaç, iyileşeceğini bildiği için, ***Diğer: Demir hapı, kas gevşetici krem

Turk J Public Health 2014;12(3) 
Katılımcılardan gençlerin, lise ve üzeri eğitime sahip olanların, aylık geliri 2001 TL ve üzeri olanların hekime başvurduğunda istediği ilacı yazdırmayı daha az talep ettiği saptanmıştır. Buna karşılık kadınların, evlilerin, hanesinde kronik hastalığa sahip, engelli ve sürekli ilaç kullanan birey olanların hekime başvurduğunda istediği ilaçları yazdırmayı daha fazla talep ettiği saptanmıştır.

Tablo 6'da araștırmaya katılanların bazı tanımlayıcı özelliklerine göre hekim önerisi/reçetesi dışında ilaç kullanma durumunun dağılımı sunulmuştur.

Katılımclardan 24 yaş ve altındakilerin \%63.6'sı, 35-44 yaş arasındakilerin \%65.1'i, erkeklerin \%62.8'i, bekârların \%62.2'si, okuryazar olanların \%75.5'i, ilkokul mezunu olanların \%64.0'ı, yüksekokul-üniversite mezunu olanların $\% 51.2$ 'si, ev hanımlarının \%64.3'ü, emeklilerin \%62.1'i, aylık toplam geliri 1000 TL ve daha az olanların \%66.0'ı, 1501 TL ile 2000 TL arasinda olanlarin \%65.9'u, hanesinde kronik hastalık olanların \%64.0'ı, hanelerinde engelli kişi olanların \%56.4'ü, hanesinde sürekli ilaç kullanan kişi olanların \%64.2'si, hekim önerisi / reçetesi hekim önerisi / reçetesi dışında ilaç kullandığını belirtmiştir. Katılımcıların yaş gruplarına, öğrenim durumlarına, mesleklerine, aylık toplam gelirlerine göre hekim önerisi/reçetesi dışında ilaç kullanma durumları arasında istatistiksel olarak anlamlı bir fark saptanmıştır $(\mathrm{p}<0.05)$. Yaş, öğrenim durumu, meslek ve aylık toplam hane geliri grupları arasındaki fark birden fazla gruptan kaynaklanmaktadır.

Katılımcılardan yaşlıların, yüksekokul / üniversite mezunu olanların, aylık geliri 2001 TL ve üzerinde olanların, hanesinde kronik hastalığ 1 ve sürekli ilaç kullanan birey olanların hekim önerisi dışında daha fazla ilaç kullandığı saptanmıștır.
Tablo 4. Araştırmaya katılanların kullandıkları ilaçların kullanım talimatını okuma durumları, ilaç kullanırken dikkat ettikleri durumlar, kullanılmayan ilaçların durumları ve reçete ile alınan ilaçların tam olarak kullanılma durumlarının dağılımı, Ankara, 2013

\begin{tabular}{|c|c|c|}
\hline Özellikler & Sayı & $(\%)^{*}$ \\
\hline \multicolumn{3}{|c|}{$\begin{array}{l}\text { Kullanılan ilaçların kullanma } \\
\text { talimatını okuma durumu (n=1962) }\end{array}$} \\
\hline Okuyor & 1195 & 60.9 \\
\hline Okumuyor & 767 & 39.1 \\
\hline \multicolumn{3}{|c|}{$\begin{array}{l}\text { İlaç kullanırken dikkat edilenler } \\
\text { (n=1947)\# }\end{array}$} \\
\hline Doktor tavsiyesi & 1824 & 53.3 \\
\hline Eczacı tavsiyesi & 527 & 15.4 \\
\hline $\begin{array}{l}\text { Yakın/komşu } \\
\text { tavsiyesi }\end{array}$ & 516 & 15.1 \\
\hline Yazılı/görsel basın & 359 & 10.4 \\
\hline İnternet & 185 & 5.4 \\
\hline Diğer** & 10 & 0.4 \\
\hline \multicolumn{3}{|c|}{$\begin{array}{l}\text { Kullanılmayan ilaçların durumu } \\
(\mathrm{n}=1939) \#\end{array}$} \\
\hline $\begin{array}{l}\text { Buzdolabinda } \\
\text { saklama }\end{array}$ & 1391 & 60.3 \\
\hline Çöpe atma & 416 & 18.0 \\
\hline $\begin{array}{l}\text { Sağlık kuruluşlarına } \\
\text { verme }\end{array}$ & 236 & 10.2 \\
\hline Arkadaşıma veririm & 205 & 8.8 \\
\hline Diğer ${ }^{* * *}$ & 58 & 2.7 \\
\hline \multicolumn{3}{|c|}{$\begin{array}{l}\text { Reçete ile alınan ilaçların tam olarak } \\
\text { kullanılma durumu }(n=1967)\end{array}$} \\
\hline $\begin{array}{l}\text { Tam olarak } \\
\text { kullanıyor }\end{array}$ & 1119 & 56.9 \\
\hline $\begin{array}{l}\text { Bazen tam olarak } \\
\text { kullanıyor }\end{array}$ & 635 & 32.3 \\
\hline $\begin{array}{l}\text { Tam olarak } \\
\text { kullanmıyor }\end{array}$ & 213 & 10.8 \\
\hline \multicolumn{3}{|c|}{$\begin{array}{l}\text { *Sütun yüzdesi, \#Birden fazla yanıt verilmiştir } \\
\text { Yüzdeler toplam yanıt verilen sayı üzerinden } \\
\text { değerlendirilmiştir, **Diğer: Kendi isteğiyle } \\
\text { ***Diğer: Eczaneye geri verme, tıbbi atı } \\
\text { kutusuna atma, çekmecede saklama }\end{array}$} \\
\hline
\end{tabular}

Turk J Public Health 2014;12(3) 
Tablo 5. Araştırmaya katılanların bazı tanımlayıcı özelliklerine göre doktora gidildiğinde istediği ilaçları yazdırmayı talep etme durumunun dağılımı, Ankara, 2013

\begin{tabular}{|c|c|c|c|c|}
\hline \multirow{3}{*}{ Tanımlayıcı özellikler } & \multicolumn{4}{|c|}{$\begin{array}{l}\text { Doktora gidildiğinde istediği ilaçları } \\
\text { yazdırmayı talep etme durumu }\end{array}$} \\
\hline & \multicolumn{2}{|c|}{ Talep etmeyen } & \multicolumn{2}{|c|}{ Talep eden } \\
\hline & Sayı & $(\%)^{*}$ & Sayı & $(\%)^{*}$ \\
\hline \multicolumn{5}{|l|}{ Yaș grupları $(n=1970)$} \\
\hline 24 yaş ve altı & 115 & 49.6 & 117 & 50.4 \\
\hline $25-34$ yaş & 224 & 44.7 & 277 & 55.3 \\
\hline $35-44$ yaş & 145 & 35.6 & 262 & 64.4 \\
\hline $45-54$ yaș & 145 & 36.0 & 258 & 64.0 \\
\hline 55 yaș ve üzeri & 133 & 31.1 & 294 & 68.9 \\
\hline $\mathrm{X}^{2}=32.332$ & \multicolumn{2}{|c|}{$\mathrm{p}<0.001$} & & \\
\hline \multicolumn{5}{|l|}{ Cinsiyet $(n=1970)$} \\
\hline Erkek & 344 & 41.0 & 496 & 59.0 \\
\hline Kadın & 418 & 37.0 & 712 & 63.0 \\
\hline$X^{2}=3.188$ & \multicolumn{2}{|c|}{$\mathrm{p}=0.074$} & & \\
\hline \multicolumn{5}{|l|}{ Medeni durum (n=1970) } \\
\hline Evli & 526 & 36.7 & 909 & 63.3 \\
\hline Bekâr & 236 & 44.1 & 299 & 55.9 \\
\hline$X^{2}=9.137$ & \multicolumn{2}{|c|}{$p=0.003$} & & \\
\hline \multicolumn{5}{|l|}{ Öğrenim durumu (n=1969) } \\
\hline Okuryazar değil & 19 & 28.8 & 47 & 71.2 \\
\hline Okuryazar & 33 & 30.0 & 77 & 70.0 \\
\hline İlkokul mezunu & 73 & 30.0 & 170 & 70.0 \\
\hline Ortaokul mezunu & 106 & 29.5 & 253 & 70.5 \\
\hline Lise mezunu & 269 & 42.3 & 367 & 57.7 \\
\hline Yüksekokul-üniversite mezunu & 262 & 47.2 & 293 & 52.8 \\
\hline$X^{2}=47.055$ & \multicolumn{2}{|c|}{$\mathrm{p}<0.001$} & & \\
\hline \multicolumn{5}{|l|}{ Meslek $(n=1925)$} \\
\hline Öğrenci & 68 & 55.3 & 55 & 44.7 \\
\hline Ev hanımı & 185 & 29.4 & 444 & 70.6 \\
\hline İşsiz & 27 & 44.3 & 34 & 55.7 \\
\hline İşçi & 72 & 36.7 & 124 & 63.3 \\
\hline Memur & 218 & 46.9 & 247 & 53.1 \\
\hline Emekli & 81 & 36.0 & 144 & 64.0 \\
\hline Serbest & 97 & 43.2 & 129 & 56.8 \\
\hline$X^{2}=54.403$ & \multicolumn{2}{|c|}{$\mathrm{p}<0.001$} & & \\
\hline \multicolumn{5}{|l|}{ Aylık aile toplam geliri $(n=1966)$} \\
\hline 1000 tl ya da daha az & 104 & 34.7 & 196 & 65.3 \\
\hline $1001 \mathrm{tl}-1500 \mathrm{tl}$ & 152 & 31.1 & 336 & 68.9 \\
\hline $1501 \mathrm{tl}-2000 \mathrm{tl}$ & 189 & 36.7 & 326 & 63.3 \\
\hline $2001 \mathrm{tl}-5000 \mathrm{tl}$ & 241 & 46.6 & 276 & 53.4 \\
\hline 5000 tl'den fazla & 75 & 51.4 & 71 & 48.6 \\
\hline $\mathrm{X}^{2}=38.189$ & \multicolumn{2}{|c|}{$\mathrm{p}<0.001$} & & \\
\hline
\end{tabular}

\footnotetext{
* Satır yüzdesi, \#Yates düzeltmeli ki kare testi uygulanmıştır
}

TurkJ Public Health 2014;12(3) 
Tablo 5. 'in devamı

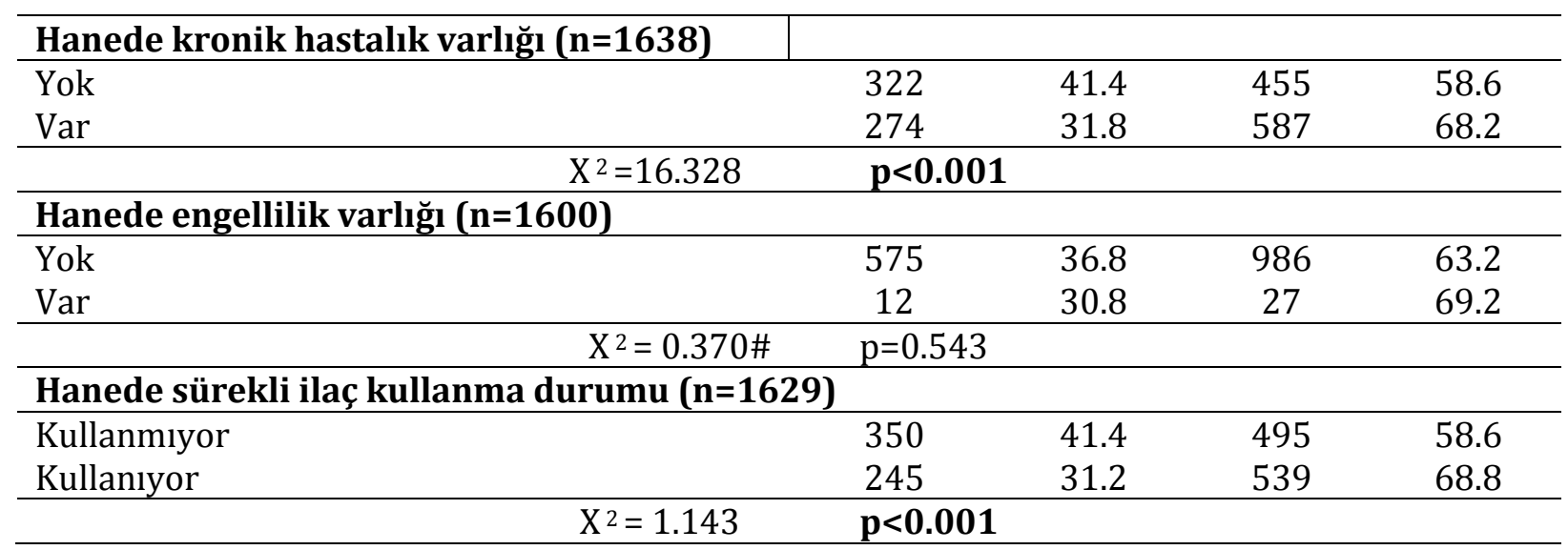

* Satır yüzdesi, \#Yates düzeltmeli ki kare testi uygulanmıştır

\section{Tartışma}

Kişilerin ilaç kullanım özelliklerinin belirlenmesinde, hekimlerin ilaç önermedeki tutumları kadar hastaların sosyodemografik özellikleri ve sosyal çevrelerinden etkilenmeleri de rol oynamaktadır.

Bu çalışmada, katılımcıların \%59.5'i sağlık sorunu olduğunda ilk olarak sağlık kuruluşuna başvurduğunu belirtirken, $\% 30.2$ 'si evdeki mevcut ilaçları kullandığını, \%20.8'i ise bitkisel / geleneksel yöntemlere bașvurduğunu ifade etmiștir. Ankara'da 2008 yılında yapılan bir araştırmada katılımcıların \%60.5’i bir sağlık problemiyle karşılaştıklarında ilk olarak doktora başvurduğunu belirtmiştir. ${ }^{5}$ Türkiye genelinde 2011 yılında yapılan "Toplumda Antibiyotik Kullanımı Sıklığı ve Hekimlerin Antibiyotik Reçetesi Yazma Durumları İle İlişkili Etmenlerin Belirlenmesi" adlı araştırmada; incelenenlerin \%65.4'ü sağlık sorunu olduğunda ilk olarak doktora başvurduğunu, \%17.1'i evdeki ilaçları kullandığını \%14.9'u bitkisel-geleneksel yöntem kullandığını belirtmiștir. ${ }^{6}$ Ankara'da 2004 yılında bir üniversite hastanesine bașvuranlar arasında yapılan bir araștırmada, hastaların \%69.5'i bir sağlık sorunuyla karșılaștıklarında ilk olarak doktora başvurduğunu belirtirken, \%15.8'i hastalığının geçmesini beklediğini, \%11.4'ü ise evdeki ilaçları kullandığını ifade etmiştir.4

Ankara'da 2002 yılında yapılmış bașka bir çalıșmada ise araștırmaya katılan bireylerin \%6.9'unun herhangi bir sağlık sorunuyla karşılaştıklarında hiçbir yere başvurmadan evdeki ilaçları kullandığı saptanmıştır. ${ }^{7} \quad \mathrm{Bu}$ çalışmada doktora başvuru yüzdesi Ankara'da yapılmış olan diğer çalışmalarla benzer saptanmış, fakat evdeki ilaçları kullanma yüzdesi benzer araştırmalara göre yüksek bulunmuştur. Sağlık sorunu olduğunda ilk olarak evdeki ilaçları kullanma sıklığının benzer çalışmalara göre yüksek bulunması; diğer çalışmaların yapıldığı tarihten bugüne kadar ilaç politikalarındaki değişime bağlı olarak ilaca ulaşımın kolaylaşmasından kaynaklanıyor 
Tablo 6. Araştırmaya katılanların bazı tanımlayıcı özelliklerine göre hekim önerisi/reçetesi dışında ilaç kullanma durumunun dağılımı, Ankara, 2013

Tanımlayıcı özellikler

Hekim önerisi/reçetesi dışında ilaç kullanma durumu

\begin{tabular}{|c|c|c|c|c|}
\hline \multirow[t]{2}{*}{ Tanımlayıcı ozellikler } & \multicolumn{2}{|c|}{ Kullanmiyor } & \multicolumn{2}{|c|}{ Kullanıyor } \\
\hline & Sayı & $(\%) *$ & Sayı & $(\%)^{*}$ \\
\hline \multicolumn{5}{|l|}{ Yaș grupları $(n=1969)$} \\
\hline 24 yaș ve altı & 87 & 36.4 & 152 & 63.6 \\
\hline $25-34$ yaş & 180 & 36.0 & 320 & 64.0 \\
\hline $35-44$ yaș & 142 & 34.9 & 265 & 65.1 \\
\hline 45-54 yaş & 178 & 44.9 & 218 & 55.1 \\
\hline 55 yaș ve üzeri & 162 & 37.9 & 265 & 62.1 \\
\hline $\mathrm{X}^{2}=10.892$ & $p=0.028$ & & & \\
\hline \multicolumn{5}{|l|}{ Cinsiyet $(n=1969)$} \\
\hline Erkek & 313 & 37.2 & 529 & 62.8 \\
\hline Kadın & 436 & 38.7 & 691 & 61.3 \\
\hline$X^{2}=0.468$ & $\mathrm{p}=0.494$ & & & \\
\hline \multicolumn{5}{|l|}{ Medeni durum (n=1969) } \\
\hline Evli & 547 & 38.1 & 888 & 61.9 \\
\hline Bekâr & 202 & 37.8 & 332 & 62.2 \\
\hline$X^{2}=0.014$ & $\mathrm{p}=0.906$ & & & \\
\hline \multicolumn{5}{|l|}{ Öğrenim durumu (n=1968) } \\
\hline Okuryazar değil & 26 & 39.4 & 40 & 60.6 \\
\hline Okuryazar & 27 & 24.5 & 83 & 75.5 \\
\hline İlkokul mezunu & 87 & 36.0 & 155 & 64.0 \\
\hline Ortaokul mezunu & 114 & 31.8 & 245 & 68.2 \\
\hline Lise mezunu & 227 & 35.2 & 417 & 64.8 \\
\hline Yüksekokul-üniversite mezunu & 267 & 48.8 & 280 & 51.2 \\
\hline $\mathrm{X}^{2}=44.086$ & $\mathrm{p}<0.001$ & & & \\
\hline \multicolumn{5}{|l|}{ Meslek (n=1925) } \\
\hline Öğrenci & 50 & 40.0 & 75 & 60.0 \\
\hline Ev hanımı & 224 & 35.7 & 403 & 64.3 \\
\hline İşsiz & 16 & 26.2 & 45 & 73.8 \\
\hline İşçi & 61 & 31.0 & 136 & 69.0 \\
\hline Memur & 214 & 46.1 & 250 & 53.9 \\
\hline Emekli & 85 & 37.9 & 139 & 62.1 \\
\hline Serbest & 79 & 34.8 & 148 & 65.2 \\
\hline$X^{2}=23.809$ & $\mathrm{p}=0.001$ & & & \\
\hline \multicolumn{5}{|l|}{ Aylık aile toplam geliri $(n=1965)$} \\
\hline 1000 tl ya da daha az & 102 & 34.0 & 198 & 66.0 \\
\hline $1001 \mathrm{tl}-1500 \mathrm{tl}$ & 175 & 35.8 & 314 & 64.2 \\
\hline $1501 \mathrm{tl}-2000 \mathrm{tl}$ & 174 & 34.1 & 337 & 65.9 \\
\hline $2001 \mathrm{tl}-5000 \mathrm{tl}$ & 229 & 44.1 & 290 & 55.9 \\
\hline 5000 tl'den fazla & 68 & 46.6 & 78 & 53.4 \\
\hline$X^{2}=19.236$ & $\mathrm{p}=0.001$ & & & \\
\hline \multicolumn{5}{|l|}{ Hanede kronik hastalık varlığı(n=1632) } \\
\hline Yok & 288 & 37.4 & 483 & 62.6 \\
\hline Var & 310 & 36.0 & 551 & 64.0 \\
\hline
\end{tabular}

Turk J Public Health 2014;12(3) 
Tablo 6'nın devamı

\begin{tabular}{|c|c|c|c|c|}
\hline \multicolumn{5}{|c|}{ Hanede engellilik varlığı $(n=1594)$} \\
\hline Yok & 569 & 36.6 & 986 & 63.4 \\
\hline Var & 17 & 43.6 & 22 & 56.4 \\
\hline & $\mathrm{p}=0.467$ & & & \\
\hline \multicolumn{5}{|c|}{ Hanede sürekli ilaç kullanma durumu ( $n=1623)$} \\
\hline Kullanmiyor & 313 & 37.3 & 526 & 62.7 \\
\hline Kullaniyor & 281 & 35.8 & 503 & 64.2 \\
\hline
\end{tabular}

* Satır yüzdesi, \#Yates düzeltmeli ki kare testi uygulanmıştır

Doktora danışmadan ilaç kullanımı değişik yaş gruplarında araştırılmış; Ankara Üniversitesi'nde 1078 öğrencinin katılımıyla 1992 yılında yapılan bir araştırmada bu hız $\% 90.2^{8}$, geriatrik yaş grubunda ise $\% 14.4^{9}$ olarak saptanmıştır. Antalya'da 1993 yılında yapılan bir çalıșmada, sağlık kurumuna başvuru öncesi ilaç kullanım sıklığı \%43.5 olarak belirlenmiştir. ${ }^{10}$ Toplumdaki bireylerin herhangi bir sağllk sorunuyla karşılaştıklarındaki davranışları; sağlığı algılamaları, sağlık bilgi düzeyleri, öğrenim durumları, sağlı kurumlarından beklentileri gibi birçok faktörden etkilenmektedir. Bu çalışmada da yaşlıların, öğrenim düzeyi düşük olanların ve daha az aylık toplam aile gelirine sahip olanların doktora gittiğinde istediği ilacı yazdırmayı daha fazla talep ettiği saptanmıştır. Bu durum yaşlıların gençlere göre kronik hastalığa daha fazla sahip olmaları ve daha fazla ilaç kullanmaları, öğrenim seviyesi ve aylık toplam aile geliri düşük olanların ilaç kullanma konusunda daha az bilinçli olabileceği ile ilişkili olabilir.

Antalya'da hanelerde kullanılmayan ilaçların durumunu araştırmak üzere 2002 yılında yapılmış bir çalışmada; evlerin \%80.0'ında ilaç bulunduğu saptanmıștır.11 Kayseri'de 2001 yılında yapılmıș bir çalışmada ise araştırmaya katılan hanelerin \%84.6'sında ağrı kesici ilaç bulunduğu belirlenmiştir. ${ }^{12}$ Bu çalışmada, katılımcıların \%78.6'sı evde ilaç bulundurduklarını ifade etmiştir. Belirtilen sıklıklar bu çalışmayla benzerdir. Ayrıca evde ilaç bulundurduğunu ifade edenlerin \%40.8'i hekimden reçete yazmasını istediğini, \%15.1'i sağlık kuruluşuna başvurmadan ilaçları eczacıya danışarak temin ettiğini belirtmiştir. Öğrenim düzeyi yükseldikçe, hekimden ilaç yazmasını isteme sıklığının azaldığ saptanmıştır ki, bu beklenen bir bulgudur. Ankara'da yapılan bir çalışmaya göre, katılımcıların \%68.4'ü doktordan ilaç yazmasını talep etmektedir. ${ }^{5} 2011$ yılında Türkiye genelinde yapılan bir çalışmada ise katılımcıların \%25.1'i ileride lazım olur diye evde antibiyotik bulundurduğunu, \%17.0'1 doktordan antibiyotik yazmasını talep ettiğini ifade etmiştir. ${ }^{6}$ Diğer ilaçlar da düşünülecek olursa, bizim çalışmamızla benzer sonuçlar çıkacağı tahmin edilmektedir. Ankara il merkezinde 2000 yılı içerisinde 387 hasta üzerinde yapılmış bir çalıșmada hastaların \%31.9'u hasta olduklarında herhangi bir sağlık kurumuna başvurmadan eczaneden ilaç aldıklarını belirtmiştir. ${ }^{13}$ Aynı araştırmaya katılanların \%56,2'si evlerinde şu anda artmış veya yedek olarak sakladıkları ilaç olduğunu belirtmişlerdir. 2001 yılında yapılan başka bir çalışmada katılanların yarıdan fazlasının (\%57.8) genellikle ya da hep reçetesiz ağrı kesici kullandığı ve \%76.6'sının evlerinde sürekli ağrı kesici bulundurduğu saptanmıștır. ${ }^{14}$

Ankara il merkezinde yapılan bir araștırmaya katılan hastaların \%39,4'ü hasta olduklarında komşuları / akrabaları / arkadaşlarının kendilerine ilaç tavsiye ettiklerini belirtmiștir. ${ }^{13}$ Ankara'da bir üniversite hastanesinde yapılan başka bir çalışmada bu oran \%25.6 olarak belirtilmiştir. ${ }^{4} \mathrm{Bu}$ çalışmada, katılımcıların \%15.1'i akraba / komşu tavsiyesine dikkat

Turk J Public Health 2014;12(3) 
ettiklerini belirtmiștir. Bu sonuçlar bize insanların ilaç kullanımı konusunda birbirlerini anlaml derecede etkilediklerini göstermektedir. $\mathrm{Bu}$ durum akılcı ilaç kullanım ilkeleriyle çelişmektedir.

Ankara'daki bir çalışmada, katılımcıların \%28.6'sı doktorun önerdiği ilaçları kullanılması gereken süreden önce kullanmayı bıraktığını belirtmiştir. ${ }^{5} \mathrm{Bu}$ çalışmada ise ilaçların tam olarak kullanılmama oranı \%10.8'dir.

İlaç türüne göre saklama koşulları değișebilmekle birlikte, genel olarak ilaçların özel bir kutuda veya dolapta saklanmasının daha uygun olacağı söylenebilir. Ayrıca, ilaçların buzdolabında saklanması da bir akılcı olmayan ilaç kullanım davranışıdır. Ankara'da 2006 yılında yapılan bir çalışmada, katılımcıların \%42.9'u ilaçları ecza dolabında veya özel bir çekmecede sakladıklarını, yaklaşık üçte biri ise ilaçların evde uygunsuz koşullarda saklandığını belirtmiştir. ${ }^{15}$ Belçika'da 2007 yılında yapılan başka bir çalışmada, evlerdeki mevcut ilaçların yaklaşık üçte birinin uygunsuz şartlarda saklandığ saptanmıştır. ${ }^{16} \mathrm{Bu}$ çalışmada da katılımcıların yaklaşık üçte biri ilaçları özel bir kutuda veya dolapta saklamadığını ifade etmiştir.

$\mathrm{Bu}$ çalışmanın kısıtlılıklarından birisi; sağlı sorunu nedeniyle birinci basamağa başvuranlar üzerinde yapıldığı için sonuçların sadece çalışma grubuna genellenebilmesidir. Bir diğer önemli kısıtlılık ise araştırmanın yapıldığı aylardır. Mevsimsel farklılıklar ilaç kullanma ve / veya bulundurma konusunda farklı tutum ve davranışlara neden olabilir. Özellikle bu çalışmanın yapıldığı kış aylarında (ocakşubat) antibiyotik ve ağrı kesici gibi ilaçların kullanımı ve evde bulundurulması artabilir.

Toplumdan örnek alınarak ve bazı tutum-davranışları (evde ilaç bulundurma gibi) gözlemleyerek, ilaç kullanım alışkanlıklarını etkileyen diğer faktörlerin daha ayrıntılı değerlendirilmesi ileriki çalışmalarda yapılmalıdır.
Bu çalışmada, katılımcıların yaklaşık yarısının herhangi bir sağlık sorunu olduğunda sağlık kuruluşuna başvurmadığı, azımsanamayacak bir kısmının ise evdeki ilaçları kullanma, bitkisel / geleneksel yöntem kullanma gibi yollara başvurduğu saptanmıştır. $\mathrm{Bu}$ durumun nedenlerinin araştırılması ve toplumu sağlık kuruluşlarını kullanmaya teşvik için gerekli önlemlerin alınması gerekmektedir. Ayrıca katılımcıların ancak yarısı reçete ile alınan ilaçları tam olarak kullandıklarını ve önemli bir bölümünün kullandıkları ilaçların kullanma talimatını okumadığını belirtmiştir. Araştırmaya katılanların büyük bölümünün ilaç kullanım özelliklerinin akılcı ilaç kullanım ilkelerine uymadığı söylenebilir. Akılcı ilaç kullanım ilkeleriyle bağdaşmayan bu gibi davranışların önüne geçilebilmesi için toplumu oluşturan bireylere akılcı ilaç kullanımına yönelik halk eğitimlerinin yapılması gerekmektedir

Gelecekte planlanan eğitim programlarına ıșık tutması ve akılcı ilaç kullanımının yaygınlaştırılması açısından, genel olarak toplumda ve diğer bazı özel hasta gruplarında (çocuklar, gebeler, yaşlılar, vb.) kullanma alışkanlıkları ve akılcı ilaç kullanımı ile ilgili durum tespitinde bulunan kapsamlı araştırmaların yapılması yararlı olacaktır.

\section{Kaynaklar}

1. World Health Organization. The Rational Use of Drugs, Report of the Conference of Experts Nairobi, 25-29 November 1985 [online]. Available at: http://apps.who.int/medicinedocs/docume nts/s17054e/s17054e.pdf. Accesed Dec 07, 2014.

2. Akıcı A, Uğurlu M. Ü, Gönüllü N, Oktay Ş, Kalaça S. Pratisyen hekimlerin akılcı ilaç kullanımı konusunda bilgi ve tutumlarının değerlendirilmesi. STED 2002;11(7):253.

3. Türkiye Cumhuriyeti Sağlık Bakanlığgl. Toplumun Akılcı İlaç Kullanımına Bakışı. Ankara: Refik Saydam Hıfzıssıhha Merkezi Başkanlığı Hıfzıssıhha Mektebi Müdürlügü; 
2001. p.11 [online]. Available at: http://www.akilciilac.gov.tr/wpcontent/uploads/2013/05/toplumun_akilci _ilac_kullanimina_bakisii.pdf. Accesed Dec 07, 2014

4. Özkan S, Özbay OD, Aksakal FN, İlhan MN, Aycan S. Bir üniversite hastanesine başvuran hastaların hasta olduklarındaki tutumları ve ilaç kullanım alışkanlıkları. TAF Prev Med Bull 2005;4(5):223-237.

5. İlhan MN, Durukan E, İlhan SO, Aksakal FN, Özkan S, Bumin MA. Self-medication with antibiotics: questionnaire survey among primary care center attendants. Pharmacoepidemiol Drug Saf 2009;18(12):1150-1157.

6. İlhan MN. Toplumda antibiyotik kullanımı sıklığı ve hekimlerin antibiyotik reçetesi yazma durumları ile ilișkili etmenlerin belirlenmesi. Ankara: 2011. p. 850. (Basılmış rapor)

7. Altıntaş H, Beyhun E, Tezcan ME, Çelebi S, Ünal M, Turan O, Yücel O. Batıkent-2 Nolu sağlık ocağı bölgesindeki Basın-iş 19 sitesinde yaşayan 15 yaş ve üstü bireylerin akılcı ilaç kullanımlarının saptanması. 8. Halk Sağlığı Günleri. Halk Sağlığı ve Sosyal Bilimler Bildiri Özetleri, Sivas 2003. p. 63.

8. Özçelikay G, Asil E, Köse K. Ankara Üniversitesi öğrencilerinin doktora gitme ve doktora başvurmadan ilaç kullanma alışkanlıkları üzerinde bir çalışma. Ankara Ecz Fak Derg 1995;24(1):21-31.

9. Esengen Ş, Seçkın Ü, Borman P, Bodur H, Gökçe-Kutsal Y, Yücel M. Huzur evinde yaşayan bir grup yaşlıda fonksiyonelkognitif değerlendirme ve ilaç kullanımı. Geriatri 2000;3(1):6-10.

10. Aktekin M, Erengin KH. Sağlık ocağı polikliniğine başvuru öncesi ilaç kullanımı. In: Aktekin M, Erengin KH, editors. Akdeniz Üniversitesi Tıp Fakültesi Halk Sağlı̆̆ Anabilim Dalı Araştırma Özetleri. Cilt 1. Antalya: 1994. p. 57.

11. Dönmez L, Yüzgül N, Anaç CC, Ödemiş Y, Özel F. Antalya merkez 6 nolu sağlı ocağı bölgesindeki hanelerde kullanılmayan ilaçların durumu. 8. Halk Sağlığı Günleri. Halk Sağlığı ve Sosyal Bilimler Bildiri Özetleri, Sivas 2003. p. 60.

12. Balcı E, Gün I, Öztürk Y. Kayseri'de 7 sağlık ocağı bölgesi'nde halkın ağrı kesici bulundurma ve kullanım özellikleri. 8. Halk Sağlığı Günleri. Halk Sağlığı ve Sosyal Bilimler Bildiri Özetleri, Sivas 2003. p. 59.

13. Mollahaliloğlu S, Tezcan S. Ankara ili merkez sağlık ocaklarından sağlık hizmeti alan hastaların akılcı ilaç kullanımı açısından değerlendirilmesi. 8. Halk Sağlığı Kongresi Kongre Kitabı, Diyarbakır 2002. p. 517-520.

14. Önder E, Koçia O, Öztürk S, Sabuncu Z, Soyutemiz Ö, Altıntaş H. Yunus Emre Sağlık ocağı bölgesinde yaşayan 18 yaş ve üstü bireylerin ağrı kesici kullanımı ve bu konudaki bazı bilgilerinin saptanması. Hacettepe Toplum Hekimliği Bülteni 2002;23(1):16-18.

15. Göçgeldi E, Uçar M, Açıkel C. H, Türker T, Hasde M, Ataç A. Evlerde artık ilaç bulunma sıklığı ve ilişkili faktörlerin araștırılması. TAF Prev Med Bull 2009;8(2):113-118.

16. De Bolle L, Mehuys E, Adriaens E, Remon JP, Van Bortel L. Home medication cabinets and self-medication: a source of potential health threats? Ann Pharmacother 2008;42(4):572-579.

Turk J Public Health 2014;12(3) 